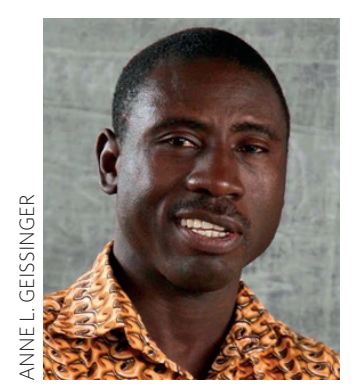

\title{
Ending child trafficking and slavery in Ghana
}

\author{
Challenging Heights - an organization that rescues and reintegrates child slaves in \\ Ghana - aims to end child trafficking in the country by 2022, says James Kofi Annan.
}

have wondered many times whether child trafficking will ever end. Many civil society organizations have invested copious resources into providing solutions, yet each year we are faced with stories of torture and exploitation of boys and girls sold into slavery. I have put so much effort into the fight against this menace.

In 2016, the Walk Free Foundation released an updated global slavery index (www.globalslaveryindex.org), estimating that there are more than 45 million people trapped in modern slavery today. There isn't a country in the world that isn't touched by modern slavery, but in Ghana, it is estimated that 103,300 people are modern-day slaves. The International Labour Organization estimates that 21,000 children are engaged in hazardous labour on Lake Volta in Ghana, the largest man-made lake in the world.

It has been 30 years since I was a victim of child slavery; at the time I did not realize that I was a victim, I took the whole enterprise to be a normal adult-child labour and apprenticeship relationship. I thought that working more than 16 hours every single day for a cumulative period of 7 years of my life was all supposed to be training for me to take up the mantle of recycling the abuse process. I would go through the torture socialization process so that when I became an adult, and I set up my own fishing business, I could acquire other children and transfer the same abuse to them in a continuous desecration of the dignity of our children.

I was able to break that cycle of slavery and abuse by pursuing my education. When I was 13 years old, an opportunity to escape presented itself; there was a vehicle heading to my hometown and I managed to escape on my own. I had never even been to school, but I knew that education was the way forward. Through hard work and discipline, I was able to not only complete primary and secondary school, but also go on to complete university and become a bank manager. I was the first person from my family and community to go to university. When I had the opportunity to leave my banking career, I felt a certain urgency to rescue those children from the clutches of pain and deprivation that I knew all too well. I knew that I had the moral duty to break the cycle. No one else that I knew had the capacity to do so, but I did.

When I started Challenging Heights, it was a mere passion. I did not know how to ask for help, so I concentrated on applying my own resources, from my work at the bank, to supporting the children who had fallen victim of fishing slavery on Lake Volta. Devoting $60 \%$ of my salary to fund Challenging Heights was therefore a very easy decision to take. The inconvenience of not having enough funds for my personal use was nothing compared with the burning that resided in me to urgently protect these children from abuse and bring them to safety.

\section{We're tackling the root causes of child trafficking, such as poverty, naivety and family separation [...] and we're working to advocate for increased government enforcement and cultural changes around trafficking.}

In 2003 I began Challenging Heights unofficially, mobilizing children in various communities to rise against wanton trafficking of children into fishing slavery. I made sure everyone was involved - women, schools, and the children themselves - while at the same time advocating for government action. By 2005 , the project had grown beyond my personal resources, and I decided to register Challenging Heights as a charity so that I could get other people's support.

I am proud to say that, so far, we have rescued and rehabilitated over 1,500 children in several communities, and supported several hundred more women and other vulnerable children, not only giving them their freedom, but also creating a resistance to slavery in their communities, tackling the root causes of child trafficking where we work. It has been 12 years of evolution for Challenging Heights, 12 years of rescues, rehabilitation, and reintegration of children who have been abused in child labour situations, and it has taken many years of strong community, national and international advocacy to bring an end to child trafficking in Ghana.

In January 2017, Challenging Heights launched an ambitious and aggressive strategic plan aimed at ending child trafficking in the fishing communities in Ghana where we work by 2022 . We plan to slowly increase the number of children we rescue over the next 5 years, starting with 75 this year and building up to over 200 children each year in 5 years' time. Our shelter will provide rehabilitation care to 1,000 children over 5 years, and through micro-grants of material goods from our reintegration efforts, we will be supporting 4,900 caregivers and siblings of reintegrated children. We're tackling the root causes of child trafficking, such as poverty, naivety and family separation, with a variety of targeted interventions and we're working to advocate for increased government enforcement and cultural changes around trafficking. We know this plan is ambitious, but we believe it is possible.

When I look back I remain proud of what we have created. It has been several years of challenges, of death threats, and of frustrations. But it has also been a good journey of love and of impact, which puts a smile on my face all the time. If there is anything that I have done that makes me feel fulfilled in life, it is creating Challenging Heights; it is because I found love in Challenging Heights; and it is because I have seen children who initially looked painfully destroyed, now come to life and have meaning; that is the shine I hope to keep.

James Kofi Annan is President of Challenging Heights, PO Box KN 1979, Kaneshie, Accra, Ghana. e-mail: info@challengingheights.org 